\title{
History and conservation status of the Antillean manatee Trichechus manatus manatus in Hispaniola
}

\author{
Haydée M. Domínguez Tejo
}

\begin{abstract}
To summarize the state of knowledge of the Endangered Antillean manatee Trichechus manatus manatus in Hispaniola, which comprises the Dominican Republic and Haiti, I reviewed documentary archives from preColumbian times to 2013. Manatees were historically abundant in Hispaniola but were hunted for centuries for their meat and other body parts for diverse uses. By the end of the 19th century manatees had become relatively rare around the island. Nevertheless, manatees remain widespread along the coast and occasionally occupy freshwater habitats in the Dominican Republic. In Haiti recent manatee sightings were restricted to two coastal areas. Currently, the manatee population of Hispaniola is perceived to be declining. The most commonly reported threats to the species include hunting, entanglement in fishing gear, boat strikes and disturbance by boat traffic, pollution, and habitat degradation and destruction. In the Dominican Republic longstanding national laws and international agreements protect the species and its habitat, and past conservation actions have raised public awareness about the status of the manatee. In Haiti knowledge of manatees is extremely limited and the species is not legally protected. I propose country-specific and binational recommendations to improve the contemporary conservation of manatees in the Dominican Republic and Haiti.
\end{abstract}

Keywords Antillean manatee, conservation status, distribution, Dominican Republic, Haiti, Hispaniola, historical data, Trichechus manatus manatus

Supplementary material for this article is available at https://doi.org/10.1017/So030605319000140

\section{Introduction}

$\mathrm{T}$ he Antillean manatee Trichechus manatus manatus, a herbivorous aquatic mammal, is categorized as Endangered on the IUCN Red List (Self-Sullivan \&

Haydée M. Domínguez Tejo (Corresponding author, (D) orcid.org/0000-00031356-3454) Universidad Autónoma de Santo Domingo, Centro de Investigaciones de Biología Marina, Avenida Alma Mater, Ciudad Universitaria, Santo Domingo, Dominican Republic. E-mail hdominguezt@gmail.com

*Also at: Duke University, Beaufort, USA

Received 28 August 2018. Revision requested 6 November 2018.

Accepted 5 February 2019. First published online 5 December 2019.
Mignucci-Giannoni, 2008), largely as a result of past uncontrolled hunting throughout the Wider Caribbean Region. In addition to hunting and fisheries bycatch, manatees are also subject to collisions with water craft, chemical and noise pollution, habitat degradation and habitat loss, among other threats, because they inhabit freshwater and shallow coastal marine environments heavily used by people (Reynolds \& Marshall, 2012; Self-Sullivan \& MignucciGiannoni, 2012). In most countries of the Wider Caribbean Region, remnant populations of the species are small and declining (UNEP, 2010). Such is the case for the Dominican Republic and Haiti, which share the island of Hispaniola, between Cuba and Puerto Rico (Fig. 1).

Historical data can be used as a baseline reference to assess the current status of species (Pauly, 1995; Swetnam et al., 1999). No formal records of catch data exist to reconstruct past manatee population sizes and trajectories in Hispaniola. However, manatees were hunted by the original inhabitants of the island and archaeological studies provide insights into manatee distribution and aboriginal uses (e.g. Fewkes, 1907; Miller, 1916; Krieger, 1929; Miller, 1929). Manatee bones have been found at archaeological sites in the Dominican Republic dating as early as 1250 BCE (Veloz Maggiolo, 1976). At the time when the Spanish arrived in the West Indies in the late 15th century, the most dominant of the Indigenous peoples of Hispaniola, the Taíno, manufactured luxury and ceremonial objects carved from manatee bones and other materials (Cassá, 1974). The Spanish word for manatee comes from the Taíno word for breast, manatí, a term they presumably adopted from the Cariban languages (Arrom, 1972). During the conquest and colonization of the West Indies the eastern part of Hispaniola was primarily a Spanish colony and the western part a French colony. Manatees were considered an extraordinary and tasty fish, and descriptions of manatees were not uncommon in accounts of European voyagers in the 15-19th centuries (Durand, 1983). Nevertheless, only a limited number of these historical documents were included in regional reviews (Lefebvre et al., 1989, 2001) and management plans for the West Indian manatee (UNEP, 1995, 2010), and pertinent literature about Hispaniola written in Spanish and French was excluded. Recent information about manatees in Hispaniola remains dispersed and mostly unpublished, hindering the assessment of the species' status and the development of recovery plans to improve its conservation. 


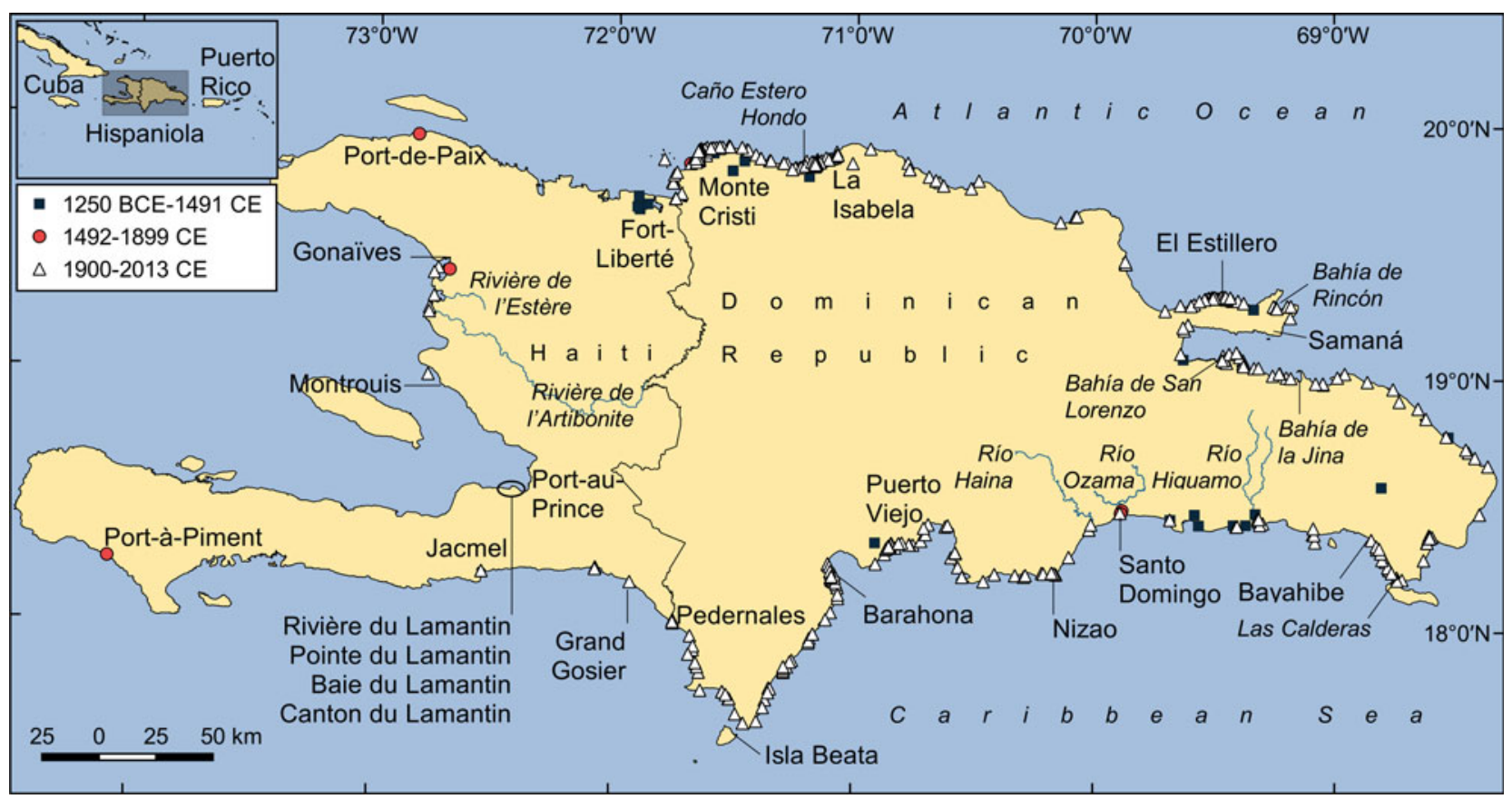

FIG. 1 Manatee sighting records in Hispaniola (Supplementary Fig. 1), with specific rivers and locations mentioned in the text. In Haiti, a former manatee river, point, bay and township were located within the enclosed area near Port-au-Prince.

To document what is known about Antillean manatees in Hispaniola, identify knowledge gaps, and recommend relevant conservation actions to protect the manatee population in the Dominican Republic and Haiti, I reviewed historical and contemporary information on the species in English, Spanish and French. Documentary archives from three time periods were reviewed: the pre-Columbian era (1250 BCE-1491 CE), 1492-1899 CE, and 1900-2013 CE (Supplementary Material 1). A comprehensive database of manatee sighting records in Hispaniola was compiled and analysed (Supplementary Material 2). My aims are to contribute to: (1) an update of the 2008 assessment of the West Indian manatee for the IUCN Red List (Deutsch et al., 2008), (2) updates of the Regional Management Plan for the West Indian Manatee (UNEP, 2010), and (3) future national manatee recovery plans of the Dominican Republic and Haiti.

\section{Distribution}

I obtained 889 manatee sighting records around Hispaniola from the documentary archives reviewed, the majority (98\%) for the Dominican Republic. Twenty-four pre-Columbian records (1250 BCE-1491 CE), comprising manatee teeth and unworked bones, bone utensils, amulets or idols and ceremonial objects, were found at archaeological sites distributed throughout the Dominican Republic (Fig. 1, Supplementary Fig. 1). Four pre-Columbian records of manatee bone fragments and utensils were found near Fort-Liberté in the north-east of Haiti (Rainey, 1941; Rouse, 1941; Fig. 1).

There were five manatee sighting records in each country for 1492-1899 CE (Fig. 1, Supplementary Fig. 1). For the
Dominican Republic, the first sighting was recorded in the $\log$ of Columbus during his first voyage to America, when he sighted three 'sirens' in January 1493 near Río Yaque del Norte, on the north-west coast (de Herrera y Tordesillas, 1726; de Charlevoix, 1731; Fernández de Navarrete, 1858; Hazard, 1873; de las Casas, 1875; Baughman, 1946; Husar, 1977). In his 1535 general history of the West Indies, Fernández de Oviedo y Valdés mentioned that manatees grazed on the banks of Río Ozama (the river that bisects Santo Domingo city), where many large manatees were harpooned from boats and canoes (Fernández de Oviedo y Valdés, 1992). The missionary de Acosta ate manatee meat in Santo Domingo in c. 1571 (de Acosta, 1590; Baughman, 1946; Husar, 1977; Lefebvre et al., 2001). Two unworked manatee ribs were recently recovered from the 1720-1723 Tile Wreck on the north-west coast (ADMAT, 2015; Supplementary Material 1). On the south-west coast, Walton (1810) sighted a manatee near Isla Beata.

According to de Charlevoix (1731), manatees were more common in Etang des Gonaïves (Gonaïves lake), on the central coast of Haiti, than in any other place in Hispaniola (Fig. 1). Moreau de Saint-Méry (1798), mentioned that manatees were frequently caught in Port-de-Paix and Port-à-Piment, on the north and south coasts of Haiti, respectively. This author also mentioned several natural features or places named after manatees that suggest they were common in an area near Port-au-Prince: Rivière Lamantin, Pointe Lamantin, Baie Lamantin and Canton du Lamantin (a manatee river, point, bay and township, respectively; Fig. 1). Today, a manatee lighthouse (Phare Lamentin) and two manatee streets (Lamentin 52, and 
TABLE 1 Details of the 13 studies dedicated to the manatee Trichechus manatus manatus in Hispaniola. NR indicates the technique was used but the value was not reported; a blank cell indicates the technique was not used.

\begin{tabular}{|c|c|c|c|c|c|c|c|}
\hline \multirow[b]{2}{*}{ References } & \multirow[b]{2}{*}{$\begin{array}{l}\text { No. of coastal } \\
\text { segments covered }\end{array}$} & \multirow[b]{2}{*}{ Interviews } & \multirow[b]{2}{*}{$\begin{array}{l}\text { No. of field- } \\
\text { work days }{ }^{4}\end{array}$} & \multicolumn{2}{|c|}{ Effort $(h)^{1}$} & \multicolumn{2}{|c|}{ Sighting records ${ }^{2}$} \\
\hline & & & & $\begin{array}{l}\text { Land/ } \\
\text { boat }\end{array}$ & Aerial & $\begin{array}{l}\text { From } \\
\text { interviews }\end{array}$ & $\begin{array}{l}\text { From field } \\
\text { work }\end{array}$ \\
\hline Campbell \& Irvine (1975) & 29 & NR & 12 & NR & NR & 5 & 1 \\
\hline Crombie (1975) & 6 & NR & 5 & NR & NR & 1 & \\
\hline Belitsky \& Belitsky (1978) & 51 & 48 & 43 & 149 & 63 & 33 & 70 \\
\hline Rathbun et al. (1985) & & NR & NR & & 13 & 3 & 4 \\
\hline \multicolumn{8}{|l|}{ Ottenwalder (1995), } \\
\hline Ottenwalder \& León $(1999)^{5}$ & 49 & 418 & 5 & & NR & 159 & NR \\
\hline Pugibet \& Vega (2000) & 26 & 50 & & & & 39 & \\
\hline Lancho et al. (2006) & 1 & 6 & 2 & 10 & & 3 & 7 \\
\hline Domínguez Tejo (2006) & 9 & 23 & 15 & 87 & & 37 & 26 \\
\hline Domínguez Tejo (2007) & 2 & 138 & 34 & 240 & & 173 & 77 \\
\hline Domínguez Tejo (2009) & 3 & 17 & 10 & 38 & & 27 & 26 \\
\hline Domínguez Tejo (2010) & 1 & & 2 & 3 & & & 3 \\
\hline Auil Gómez et al. (2011) & 10 & 63 & 22 & 65 & 5 & NR & 13 \\
\hline Reynoso et al. (2011) & 12 & & 10 & & 36 & & 25 \\
\hline
\end{tabular}

${ }^{1}$ Approximate survey effort in hours.

${ }^{2}$ Number of manatee sightings from interviews or fieldwork that were included in the database.

${ }^{3}$ Number of coastal segments of the Dominican Republic covered by the study, from a maximum of 51 (Supplementary Fig. 2).

${ }^{4}$ Number of days spent conducting land, boat or aerial surveys.

${ }^{5}$ Results of the studies were pooled because they were part of the same project managed by the NGO Prospectiva Ambiental Dominicana.

Lamatin 54) remain in that area. Descourtilz (1809) mentioned that manatees were sometimes found in Rivière de l'Artibonite, but more particularly in Rivière de l'Estère, and that manatees were commonly hunted in the rivers.

There were 838 recent $(1900-2013 \mathrm{CE})$, widespread sighting records in the Dominican Republic, mostly concentrated in six areas: from Monte Cristi to La Isabela; on the north coast of the Samaná peninsula; from Bahía de San Lorenzo to Bahía de la Jina; from Bayahibe to Las Calderas; from Nizao to Puerto Viejo; and from Barahona to Pedernales (Fig. 1). In Haiti 13 records were found in only two areas: Gonaïves to Montrouis on the central coast, and Jacmel to Grand Gosier on the south-east coast. The most recent sightings in Haiti were from 2007-2013. Regarding current use of freshwater habitats, fishers in the Dominican Republic have reported manatees in Río Higuamo since the 1960s, and as recently as 2009 (Fig. 1). One manatee was found in Río Haina in 2012. In contrast, there have been no recent sightings in rivers in Haiti.

Thirteen recent studies collected data on manatees in Hispaniola (Table 1). The only study in Haiti (Rathbun et al., 1985) comprised a 12.5 hour countrywide aerial survey in 1982 and interviews conducted in 1982-1983, with few manatee sightings. To compare the spatial coverage of the dedicated manatee studies conducted in the Dominican Republic, I used as a reference coastal segments of c. $30 \mathrm{~km}$ defined by Belitsky \& Belitsky (1978; Supplementary Fig. 2), determining the number of segments covered by each study (Table 1). In general, studies conducted from 2006 onwards covered fewer coastal segments than earlier studies, but several included multiple visits to the same areas, and geographical coordinates of manatee sightings were recorded more accurately (Domínguez Tejo, 2007; Auil Gómez et al., 2011; Reynoso et al., 2011).

The study by Belitsky \& Belitsky $(1978,1980)$ is the most complete to date for the Dominican Republic, with countrywide aerial surveys and interviews conducted during $1976-$ 1977 (Table 1). Ottenwalder \& León (1999) included $>400$ countrywide interviews completed in 1994-1996, but the results remain unpublished. Aerial surveys planned in that study were not completed because of a tragic accident in 1995, and only general information was published (Ottenwalder, 1995).

Year-round presence of manatees has been confirmed in Caño Estero Hondo (Domínguez Tejo, 2006, 2007, 2009) (Fig. 1), a mangrove lagoon on the north-west coast of the Dominican Republic where manatee watching is now the main attraction. A manatee habitat modelling study was also conducted for the lagoon, using generalized linear models and simulations to relate manatee presence to habitat variables (Domínguez Tejo \& Rivas, 2011). The two most recent dedicated manatee studies included aerial surveys on the north-east (Auil Gómez et al., 2011) and south-west (Reynoso et al., 2011) coasts, but produced relatively few sightings (Table 1 ).

Several generalizations can be made from the manatee sighting records around Hispaniola. In the Dominican Republic, both historical (prior to 1900) and recent manatee sightings are widespread (Fig. 1, Supplementary Fig. 1). Although their habitat is primarily marine in the 
TABLE 2 Indications of manatee abundance, mortality and population trend in Hispaniola based on documentary archives (Supplementary Material 1).

\begin{tabular}{|c|c|c|c|}
\hline Reference (by period) & Abundance & Mortality (deaths/year) & Population trend \\
\hline \multicolumn{4}{|l|}{1250 BCE-1491 CE } \\
\hline Mañón Arredondo et al. (1971) & Abundant & & \\
\hline Veloz Maggiolo (1972) & Abundant & & \\
\hline Soto-Ricart \& Rodríguez (1989) & Abundant & & \\
\hline \multicolumn{4}{|l|}{$1492-1899 \mathrm{CE}^{1}$} \\
\hline Vega (1983) [Cuneo, 1495] $]^{2}$ & Abundant & & \\
\hline MacNutt (1912) [de Anglería, 1530] ${ }^{2}$ & Abundant & & \\
\hline Fernández de Oviedo y Valdés (1992) & Abundant & Many & \\
\hline de Charlevoix (1731) & Abundant & & \\
\hline Lyonnet (1800-1810) & Abundant & & \\
\hline Moreau de Saint-Méry (1798) & Abundant & Many & \\
\hline Descourtilz (1809) & Abundant & Many & \\
\hline Hazard (1873) & Rare & & Declining \\
\hline \multicolumn{4}{|l|}{ 1900-2013 CE } \\
\hline Campbell \& Irvine (1975) & & 3 & Declining \\
\hline Crombie (1975) & & & Declining \\
\hline Belitsky \& Belitsky (1978) & 60 (95\%CI 41-402) & & Declining \\
\hline Thornback \& Jenkins (1982) & Rare & & \\
\hline Rathbun et al. (1985) & Rare & & Declining \\
\hline Lefebvre et al. (1989) & Never abundant & & \\
\hline Woods \& Ottenwalder (1992) & Rare & & \\
\hline Ottenwalder (1995) & $<60$ & $5-15$ & Declining \\
\hline Ottenwalder (1996) & $8^{3}$ & & \\
\hline Ottenwalder \& León (1999) & & $9-23$ & Declining \\
\hline LaBastille (1999) & & & Declining \\
\hline Pugibet \& Vega (2000) & $30-45$ & $3-5$ & Declining \\
\hline Lefebvre et al. (2001) & $<200$ & $5-15$ & Declining \\
\hline D’Ocampo (2004) & $7-8^{3}$ & & \\
\hline Lancho et al. (2006) & $15-20^{3}$ & & \\
\hline Domínguez Tejo (2006) & $<10^{4}$ & & \\
\hline Domínguez Tejo (2007) & $10-15^{3}$ & $1-2^{3}$ & Increasing $^{3}$ \\
\hline Domínguez Tejo (2009) & $<10^{5}$ & $0-1^{5}$ & Increasing ${ }^{5}$ \\
\hline Reynoso et al. (2011) & Not abundant & & Stable/declining \\
\hline
\end{tabular}

${ }^{1}$ References from this period are ordered chronologically by birth year of the original author, not by publication year.

${ }^{2}$ Original author noted in square brackets.

${ }^{3}$ Estimates for the Caño Estero Hondo-La Isabela area only.

${ }^{4}$ Individual estimates for three areas: Las Calderas, in La Altagracia province; near Barahona town, in Barahona province; Bahía de Rincón, in Samaná province.

${ }^{5}$ Estimates for El Estillero only, on the north coast of Samaná province.

Dominican Republic, as noted earlier by Belitsky \& Belitsky $(1978,1980)$ and supported by the majority of sighting records (Fig. 1), manatees also inhabit mangrove lagoons with brackish water (Domínguez Tejo, 2007) and occasionally rivers. Current knowledge of manatees in Haiti is limited but historical records show that they were once widely distributed along the coast and occupied freshwater habitats. The few dedicated manatee studies conducted in Hispaniola have been discontinuous in time and have lacked uniformity in spatial coverage, survey methods and survey effort (Table 1). The most recent studies have focused on smaller areas but collected higher quality data than earlier studies. Compared with other methods, traditional, manned aerial surveys have yielded few manatee sightings and may not be cost effective in Hispaniola.

\section{Abundance, mortality and population trends}

Manatees were historically abundant in Hispaniola (Table 2). Some authors from 1492-1899 CE, including Cuneo (Vega, 1983), de Charlevoix (1731) and Lyonnet (180o-1810), commented on the abundance of fish in Hispaniola, which at the time included manatees. Others explicitly referred to manatees. One of the major chroniclers of the West Indies, de Anglería, noted that manatees were found in great numbers in the waters of Hispaniola (MacNutt, 1912). Fernández de Oviedo y Valdés (1992) testified to the abundance of manatees in Río Ozama and stated that they were frequently killed in the larger rivers of Hispaniola. In Haiti, Moreau de Saint-Méry (1798) mentioned how frequently manatees were caught in Port-à-Piment and Port- 
de-Paix. Descourtilz (1809) specified that the best time of day to hunt manatees was 12.00-14.00, when they grazed on the banks of Rivière de l'Estère and Rivière de l'Artibonite. Probably as a result of overharvest, manatees had become rare by the end of the 19th century. Hazard (1873) mentioned that manatees were formerly more plentiful and were found only rarely.

There is no reliable estimate of the manatee population size in Hispaniola. Aerial surveys were not designed to generate abundance estimates, and estimates derived from interviews were educated guesses at best. In the Dominican Republic, the highest countrywide estimates were those of Belitsky \& Belitsky (1978), who estimated 60 animals (95\% CI 41-402), and Ottenwalder, who estimated $<200$ animals (Lefebvre et al., 2001).

Early estimates of manatee mortality in Hispaniola are qualitative (Table 2). Many manatees were killed in the 16-19th centuries but there is no evidence of their commercial exploitation in Hispaniola. During $1500-1800$ the island's major exports switched from gold to sugar, leather, livestock, ginger, cocoa, tobacco and wood (Cassá, 1978). During that period, manatee meat may have been imported from South America to Hispaniola, as it was to other Caribbean islands (Lefebvre et al., 2001).

Recent annual mortality estimates for the Dominican Republic were 3-23 individuals (Table 2). Ottenwalder (1995) stated that 5-15 manatees were captured annually (most intentionally), in addition to an unknown level of natural mortality. From countrywide interviews, Ottenwalder \& León (1999) estimated a mean annual mortality of 23 animals. It is clear that the manatee population declined in Hispaniola during the last century (Table 2), although in recent years interviewees perceived local increases in Caño Estero Hondo and El Estillero (Domínguez Tejo, 2007, 2009; Fig. 1).

In Hispaniola manatees have been hunted most commonly with nets and harpoons; current capture methods include the use of beach seines, gill nets, spear guns and traps (Supplementary Table 5). Manatees were hunted primarily for their meat, but the use of manatee body parts diversified with time to include their oil, skin and bones (Supplementary Table 6). Traditional uses of manatee oil and bones for folk medicine and handcrafts persist today in the Dominican Republic (Ottenwalder, 1995; Ottenwalder \& León, 1999; Domínguez Tejo, 2007). Details on manatee hunting methods and uses in Hispaniola are described in Supplementary Material 4.

\section{Current threats}

Current threats to manatees in Hispaniola are mostly anthropogenic and include hunting, fisheries bycatch caused by entanglement in fishing gear, boat strikes and disturbance by boat traffic, contamination, habitat degradation and destruction, and others (Supplementary Material 5, Supplementary Table 7). According to Ottenwalder (1995), the main cause of manatee mortality in the Dominican Republic is illegal hunting, and the main driver of this activity is demand for meat, which is sold quickly; in many cases the skeleton is buried and bones are retrieved later for commercial and medicinal purposes. The use of nets across river mouths and in some marine protected areas, where such use is prohibited, poses a threat to manatees (Ottenwalder, 1995; Domínguez Tejo, 2006), as do unattended nets (Reynoso et al., 2011). Net types involved in manatee hunting and fisheries bycatch include gill nets, beach seines and trawl nets (Pugibet \& Vega, 2000). In Haiti, Rathbun et al. (1985) reported that manatees were hunted traditionally with a spear, for eating and selling, and were caught accidentally in beach seines.

Anecdotes of manatee boat strikes were reported during interviews in the Dominican Republic (Domínguez Tejo, 2007; Betancourt, 2010), but no evidence of these events (e.g. images or necropsy reports of manatees injured or killed by boats) was found in the documentary archives reviewed. However, the abundance of fishing boats (Crombie, 1975) and disturbance by boat traffic (Belitsky \& Belitsky, 1978; Ottenwalder \& León, 1999) have been reported as threats to manatees in the Dominican Republic since the mid 1970s. High speed tourism boat traffic poses a threat to manatees in Bahía de San Lorenzo and its surroundings (Domínguez Tejo, 2006) and in coastal areas adjacent to Caño Estero Hondo (Domínguez Tejo, 2007; Fig. 1). Boat strikes are therefore probably an emerging or potential threat to manatees in the Dominican Republic. In contrast, manatee boat strikes may be negligible in Haiti because most watercraft are non-motorized (Mateo \& Haughton, 2003).

Coastal development, especially for tourism, has resulted in habitat degradation or destruction in many parts of the Dominican Republic (Belitsky \& Belitsky, 1978; Pugibet \& Vega, 2000; Lefebvre et al., 2001). Polluted coastal waters (Ottenwalder \& León, 1999; Domínguez Tejo, 2006, 2007; Auil et al., 2011; Reynoso et al., 2011), marine debris and ghost nets (Pugibet \& Vega, 2000) are also reported as threats.

Lax manatee-related law enforcement in the Dominican Republic has multiple causes. Local authorities may lack the directive and the necessary training, equipment and logistical support to patrol areas effectively and regularly, so manatee captures may be hidden (Ottenwalder, 1995; Ottenwalder \& León, 1999; Pugibet \& Vega, 2000; Domínguez Tejo, 2006).

Commerce in manatee products has not been formally studied in Hispaniola but, during a visit to the city market of Santo Domingo in the Dominican Republic in 1990, several stores offered polished and carved manatee ribs as ornaments and manatee oil to treat colds (Mignucci-Giannoni, 1991). It is unclear whether this illegal commerce is increasing or decreasing. 
The only reported natural threats to manatees in Hispaniola are shark predation (Belitsky \& Belitsky, 1978, 1980; D'Ocampo, 2004) and hurricanes (Ottenwalder \& León, 1999). No manatee health assessments have been conducted. Diseases and parasites have not been formally studied, except for a single case in the Dominican Republic in 1995 (Mignucci-Giannoni et al., 1999). Current knowledge of the genetic structure of the population is based on two studies that revealed the manatee population of the Dominican Republic is part of the Florida, Bahamas and Greater Antilles biogeographical group of the West Indian manatee Trichechus manatus (García-Rodríguez et al., 1998; Vianna et al., 2006). However, in both studies the sample size was limited to six individuals from the Dominican Republic. More research is needed on diseases, contaminant loads and the genetic structure of the manatee population of Hispaniola.

\section{Legal status and conservation actions}

Details on the legislation protecting manatees and their habitat in Hispaniola are presented in Supplementary Material 5. As contracting parties to the Convention on Biological Diversity, both the Dominican Republic and Haiti are responsible for promoting the recovery of threatened species and developing or maintaining legislation for their protection. In the Dominican Republic manatees have been protected since 1938 under Fishery Law 1518 (Ley de Pesca No. 1518, 1938), and several international and national legal instruments are in place to protect the species and its habitat (Supplementary Tables 8-10). In particular, with the ratifications of CITES in 1982 and the Protocol Concerning Specially Protected Areas and Wildlife in 1998, and with the enactment of the General Law of the Environment and Natural Resources in 2000 (Ley No. 64-00, 2000), the Dominican Republic prohibited the taking, possession or killing and the commercial trade of manatees, their parts or products. In 2011, manatees were officially categorized as Critically Endangered in the country (Ministerio de Medio Ambiente y Recursos Naturales, 2011). In contrast, Haiti has neither ratified CITES nor the Protocol (Supplementary Table 8). Moreover, without national legislation specifically designating manatees as a threatened species, they are not protected in Haiti. Although not specific to manatees, a 1978 fisheries decree (Décret Réglementant l'Exercice du Droit de Pêche en Haiti, 1978) prohibits the use of harpoons for fishing and could offer protection to manatees if strictly implemented.

In terms of manatee habitat protection, the Dominican Republic possesses an extensive system of marine protected areas, including two marine mammal sanctuaries for which a conservation plan (Domínguez et al., 2010) and official management plans were recently developed (Ministerio de Medio Ambiente y Recursos Naturales,
2014, 2015). These plans include, for the first time, specific objectives and conservation actions for manatees.

Following the ecosystem services assessment and the sites proposed by the local NGO Fondation pour la Protection de la Biodiversité Marine (Wiener, 2013), the Haitian government recently created two marine protected areas that enclose extensive coastal areas recognized as optimal manatee habitat (Rathbun et al., 1985): one on the south-west coast (Arrêté Déclarant l'Aire Protégée de Ressources Naturelles Gérées de Port-Salut/Aquin, 2013), and one on the north-east coast (Arrêté Déclarant l'Aire Protégée de Ressources Naturelles Gérées des Trois Baies, 2014; Supplementary Table 10).

Other manatee conservation efforts in the Dominican Republic have focused on community outreach and education, and the rescue and rehabilitation of stranded animals. In 1994-1995 a local NGO conducted a manatee research project (Ottenwalder, 1995; Ottenwalder \& León, 1999) and a national manatee educational campaign. The campaign included over 30 talks, conferences and workshops, and 5,000 posters distributed nationwide (Prospectiva Ambiental Dominicana, 1995). The project received extensive media coverage, increasing public awareness of the conservation status of manatees, and promoting the need to increase their protection among authorities and local communities. During 2005-2010 the Centro de Investigaciones de Biología Marina of the Universidad Autónoma de Santo Domingo and the Fundación Dominicana de Estudios Marinos led several manatee workshops and educational activities throughout the country.

The Red Dominicana de Varamientos (Dominican Stranding Network) was established in 1995, based at the Acuario Nacional (National Aquarium), to study, rescue and rehabilitate stranded marine mammals; in 2008, these duties were transferred to the Centro de Rescate y de Rehabilitación de Especies Acuáticas (Aquatic Species Rescue and Rehabilitation Centre). Manatees are the most commonly stranded marine mammal species in the country: most of the cases have been dead strandings with an undetermined cause of death (Veras Mena, 2014). Three successful manatee rehabilitations were identified in the documentary archives: a highly publicized case of an orphaned male calf rescued in 1995 (Ottenwalder, 1995) that survived in captivity until 2007, and two calves rescued in 2012 that are currently housed at the Acuario Nacional. These captive manatees have not only played an important role in outreach and educational activities at the Acuario Nacional, but also in raising public awareness about manatees nationally. However, no manatee reintroductions have been attempted in the Dominican Republic and a national manatee recovery plan has not yet been developed.

In Haiti marine mammal conservation efforts are relatively recent and do not focus exclusively on manatees. The Haiti Ocean Project, a collaboration between Haiti, the Dominican Republic and the USA, has focused on marine 
mammal research, education and ecotourism (Vail et al., 2011), gathering data on marine mammal sightings in Haiti through field surveys and fishing tours. Both Fondation pour la Protection de la Biodiversité Marine and the Haiti Ocean Project offer outreach and educational programmes about the marine environment and marine mammals in general. No marine mammal stranding network has yet been established.

\section{Conservation recommendations}

Based on this review I make the following recommendations for manatee conservation, prioritized by country, starting with those aiming to reduce anthropogenic mortality and habitat degradation (Supplementary Table 7), followed by those focused on education, research, management and legislation needs. Finally, I propose research and conservation measures that require coordinated actions between both countries as well as international expertise. The organizations and/or groups of actors best suited to implement each recommendation are indicated in parentheses.

Recommendations for the Dominican Republic:

(1) Increase coastal patrolling and train law enforcement agents to prosecute offenders, to halt illegal hunting of manatees (Ministerio de Medio Ambiente y Recursos Naturales (MIMARENA), Marina de Guerra).

(2) Regulate boat traffic and the use of beach seines, gill nets and trawl nets in the six identified coastal areas where most recent manatee sightings have been reported (Fig. 1; MIMARENA, Marina de Guerra, Consejo Dominicano de Pesca y Acuicultura).

(3) Enforce existing laws regarding the issuance of environmental permits for coastal development projects that may negatively impact manatee habitat (MIMARENA).

(4) Enforce existing laws regarding the illegal trade of manatee products (Supplementary Material 4-5; MIMARENA).

(5) Continue organizing education and awareness campaigns for coastal communities, to reinforce the need to protect manatees and to discourage illegal hunting and the use of manatee body parts for folk medicine and handcrafts (Supplementary Material 4-5; MIMARENA, local universities and NGOs).

(6) Systematically assess disease and parasite loads of rescued manatees and recovered manatee carcasses, and initiate sample collections for future genetic and contaminant studies (Centro de Rescate y de Rehabilitación de Especies Acuáticas (CERREA)).

(7) Reintroduce rehabilitated manatees back to the wild (CERREA).
Recommendations for Haiti:

(8) Enforce the prohibition of harpoon fishing under the 1978 fisheries decree (Supplementary Material 5) and update the regulations on the use of beach seines, to reduce manatee captures (Service des Pêcheries).

(9) Implement a national manatee education and awareness campaign for fishers, with the goal of reducing manatee captures (Ministère de l'Environnement (MdE), local NGOs).

(10) Conduct more dedicated manatee studies and confirm current and former habitat. These studies could combine interviews and reconnaissance boat trips with local guides to the areas where manatees have been reported recently and historically (Fig. 1), to confirm manatee presence and identify high-use areas and site-specific threats to the species (local and international universities, research institutes, NGOs).

(11) Establish a marine mammal stranding network. Similar to the Dominican Republic, manatees may be the most commonly stranded marine mammal in Haiti, and stranding events could contribute information on the species' distribution, health and mortality, and on any threats (MdE, local NGOs).

(12) Develop national legislation that specifically protects manatees (Supplementary Material 5; MdE, Parlement Haitien).

(13) Declare more marine protected areas that include manatee habitat as confirmed by new dedicated manatee studies (MdE, Parlement Haïtien).

(14) Ratify CITES, the Protocol Concerning Specially Protected Areas and Wildlife, and the Convention on the Conservation of Migratory Species of Wild Animals. The latter could provide a platform to promote future binational manatee conservation actions with the Dominican Republic (Supplementary Material 5; Parlement Haïtien).

Binational recommendations:

(15) Develop national manatee recovery plans that facilitate coordinated conservation actions between the Dominican Republic and Haiti (MIMARENA, MdE).

(16) Conduct telemetry studies in concert with health assessments and genetic sampling of wild animals to identify habitats highly used by manatees, establish a baseline of manatee health, and identify potential concerns for the manatee population regarding diseases, contaminant loads and genetic structure (local and international universities, research institutes, NGOs).

(17) Obtain a reliable estimate of the total size of the manatee population in Hispaniola, or a reliable estimate of the population trend, to use as a baseline to 
measure the success of future conservation actions (local and international universities, research institutes, NGOs).

Despite the historical decline of manatees in Hispaniola their future is not necessarily bleak. Conservation actions in the Dominican Republic since the late 1930s have increased the protection of the species and its habitat. Since 2000, Haiti has taken steps for the conservation of marine mammals and marine protected areas in general. This review and additional content in Domínguez Tejo (2016) served as the basis for reports on the status of the Antillean manatee in the Dominican Republic and Haiti prepared for IUCN (Domínguez Tejo, 2018a,b). The recommendations for Haiti were consulted as part of the 2017-2027 management plan for the Aire Protégée de Ressources Naturelles Gérées des Trois Baies in north-east Haiti (Henwood et al., 2017), which considers several programmes with objectives and actions relevant to the manatee, such as a permanent closure of the harvesting of marine mammals, the protection of seagrass beds, and the regulation and control of fishing and coastal development. The recommendations were also shared with relevant authorities during the celebration of the first National Manatee Day in the Dominican Republic (Domínguez Tejo et al., 2018). The Acuario Nacional and CERREA have since then expressed interest in adopting protocols for the return of rehabilitated manatees to the wild.

Acknowledgements This research was supported by the FulbrightMESCyT Program, the Faculty for the Future Fellowship from the Schlumberger Foundation and the Duke Graduate School. I thank the many organizations and colleagues who helped compile manatee sightings in Hispaniola for over a decade (in particular Yolanda León, Mónica Vega, Peter Sánchez, Omar Shamir Reynoso, José Alejandro Alvarez, José A. Ottenwalder and Jean Wiener), and Andy Read and three anonymous reviewers for their constructive comments.

\section{Conflicts of interest None.}

Ethical standards This study abided by the Oryx guidelines on ethical standards. It was based on a review of documentary archives that were retrieved in the USA and the Dominican Republic. The research did not involve human subjects, animal captures nor the collection of specimens. The results will be made available to government authorities in the Dominican Republic and Haiti upon publication.

\section{References}

ADMAT (2015) Tile Wreck 2017 Project Background. Http://www. admat.org.uk/tile-wreck-2015-project-background [accessed 8 July 2017].

Arrêté Déclarant l'Aire Protégée de Ressources Naturelles Gérées de Port-Salut/Aquin (2013) Le Moniteur 156. Port-au-Prince, Haiti, 26 August 2013.
Arrêté Déclarant l'Aire Protégée de Ressources Naturelles Gérées des Trois Baies (2014) Le Moniteur 54. Port-au-Prince, Haiti, 21 March 2014.

Arrom, J.J. (1972) Manatí: el testimonio de los cronistas y la cuestión de su etimología. Boletín del Museo del Hombre Dominicano, 2, 33-38.

Auil Gómez, N., Ross, M., Clary, D., Malaret, J. \& Taylor, C. (2011) Manatees in the Bahía de Samaná, Dominican Republic. In Abstracts of the International Sirenian Symposium. Society for Marine Mammalogy, Tampa, USA.

BAughman, J.L. (1946) Some early notices on American manatees and the mode of their capture. Journal of Mammalogy, 27, 234-239.

Belitsky, D.W. \& Belitsky, C.L. (1978) The Manatee, Trichechus manatus, in the Dominican Republic: Distribution and Abundance (Serie Publicaciones Científicas Núm. 1). Dirección Nacional de Parques, Santo Domingo, Dominican Republic.

Belitsky, D.W. \& Belitsky, C.L. (1980) Distribution and abundance of manatees (Trichechus manatus) in the Dominican Republic. Biological Conservation, 17, 313-319.

Betancourt, L. (2010) Resultados del Levantamiento de Información Biológica Pesquera y Socioeconómica en Apoyo a la Zonificación Marina de la Bahía de Samaná. Programa de la USAID para la protección ambiental/USAID (EPP), Santo Domingo, Dominican Republic.

Campbell, H.W. \& Irvine, B.I. (1975) Trip Report; Manatee Survey in Dominican Republic, Feb. 14-25, 1975. Unpublished report. National Fish and Wildlife Laboratory, Gainesville, USA.

CASSÁ, R. (1974) Los Taínos de la Española. Editora de la UASD, Santo Domingo, Dominican Republic.

CAsSÁ, R. (1978) Historia Social y Económica de la República Dominicana. Editora Alfa y Omega, Santo Domingo, Dominican Republic.

Crombie, R.I. (1975) Manatee Survey of the South-Eastern Tip of the Republica Dominicana. Unpublished report. National Fish and Wildlife Laboratory, Gainesville, Florida.

Décret Réglementant l'Exercice du Droit de Pêche en Haiti (1978) Le Moniteur 81, Port-au-Prince, Haiti, 20 November 1978.

Deutsch, C.J., Self-Sullivan, C. \& Mignucci-Giannoni, A. (2008) Trichechus manatus. In The IUCN Red List of Threatened Species 2008. Http://dx.doi.org/10.2305/IUCN.UK.2008.RLTS. T22103A9356917.en [accessed 5 May 2016].

De Acost A, J. (1590) Historia Natural y Moral de las Indias. Casa de Juan de Leon, Seville, Spain.

de Charlevoix, F.X. (1731) Histoire de l'Isle Espagnole ou de S. Domingue. Chez PRALARD, Paris, France.

de Herrera y Tordesillas, A. (1726) Historia General de los Hechos de los Castellanos en las Islas i Tierra Firme del Mar Oceano. Imprenta Real de Nicolas Rodríguez Franco, Madrid, Spain.

DE Las Casas, B. (1875) Historia de las Indias. Imprenta de Miguel Ginesta, Madrid, Spain.

Descourtilz, M.E. (1809) Voyages d'un Naturaliste. Dufart Père, Paris, France.

D’Ocampo, M. (2004) Informaciones técnicas sobre experiencias y observaciones de mamíferos marinos en el Caño Estero Hondo y sus zonas aledañas en la Provincia de Montecristi, República Dominicana. In Taller Actualización de Informaciones sobre Mamíferos Marinos del Parque Nacional del Este, Santo Domingo, Dominican Republic.

Domínguez Tejo, H.M. (2006) Evaluaciones Preliminares de Áreas con Registros Previos de Presencia de Manatíes (Contrato No. 10-6-o6). Centro de Investigaciones de Biología Marina, Santo Domingo, Dominican Republic.

Domínguez Tejo, H.M. (2007) Estudio Preliminar Sobre el Manatí Antillano Trichechus manatus manatus en el Santuario de Mamíferos Marinos de Estero Hondo, República Dominicana. 
Centro de Investigaciones de Biología Marina, Santo Domingo, Dominican Republic.

Domínguez Tejo, H.M. (2009) Estudio de Factibilidad para Realizar Proyectos de Foto Identificación de Manatíes en el Santuario de Mamíferos Marinos de Estero Hondo y la Costa Norte de la Península de Samaná. Centro de Investigaciones de Biología Marina, Santo Domingo, Dominican Republic.

Dominguez Tejo, H.M. (2010) Marine Mammal Sanctuary of Estero Hondo, Dominican Republic: Save the Manatee Club Donation Supporting the Park Rangers. Unpublished report. Centro de Investigaciones de Biología Marina, Santo Domingo, Dominican Republic.

Dominguez Tejo, H.M. (2016) Distribution and conservation of the Antillean manatee in Hispaniola. PhD thesis, Duke University, Durham, USA.

Domínguez Tejo, H.M. (2018a) Survey of Trichechus manatus manatus in the Dominican Republic for the IUCN Red List of Threatened Species Status for 2018. Unpublished report. Centro de Investigaciones de Biología Marina, Santo Domingo, Dominican Republic.

Domínguez Tejo, H.M. (2018b) Survey of Trichechus manatus manatus in Haiti for the IUCN Red List of Threatened Species Status for 2018. Unpublished report. Centro de Investigaciones de Biología Marina, Santo Domingo, Dominican Republic.

Domínguez Tejo, H.M., Reynoso, O.S., Delance, J. \& del Cid, M. (2018) First ever manatee day celebration in the Dominican Republic. Sirenews, 68, 8-9.

Dominguez Tejo, H.M. \& Rivas, D.V. (2011) Quantitative assessment of habitat use of Antillean Manatees in Caño Estero Hondo, Dominican Republic. In Abstracts of the 19th Biennial Conference on the Biology of Marine Mammals. Society for Marine Mammalogy, Tampa, USA.

Domínguez Tejo, H.M., Rivas, V., Mateo, A. \& Voss, A. (2010) Plan de Conservación del Santuario de Mamíferos Marinos Estero Hondo. The Nature Conservancy/Centro de Investigaciones de Biología Marina, Santo Domingo, Dominican Republic.

Durand, J. (1983) Ocaso de Sirenas: Esplendor de Manatíes. Fondo de Cultura Económica, Ciudad de México, México.

Fernández de Navarrete, M. (1858) Colección de los Viajes y Descubrimientos que Hicieron por mar los Españoles desde Fines del Siglo XV. Imprenta Nacional, Madrid, Spain.

Fernández de Oviedo y Valdés, G. (1992) Historia General y Natural de las Indias. Ediciones Atlas, Madrid, Spain.

Few kes, J.W. (1907) The Aborigines of Puerto Rico and Neighboring Islands. University of Alabama Press, Alabama, USA.

García-Rodríguez, A.I., Bowen, B.W., Domning, D., Mignucci-Giannoni, A.A., Marmontel, M., MontoyaOspina, R.A. et al. (1998) Phylogeography of the West Indian manatee (Trichechus manatus): how many populations and how many taxa? Molecular Ecology, 7, 1137-1149.

HaZard, S. (1873) Santo Domingo, Past and Present; with a Glance at Hayti. Harper \& Brothers, New York, USA.

Henwood, W.D., Aucoin, S. \& Turner, M. (2017) The Protected Area of Managed Natural Resources of the Three Bays. Management Plan 2017-2027. Fondation pour la Protection de la Biodiversité Marine, The Nature Conservancy and The National Agency of Protected Areas, Haiti.

Husar, S.L. (1977) The West Indian Manatee (Trichechus manatus) (Wildlife Research Report 7). United States Department of the Interior, U.S. Fish \& Wildlife Service, Washington, DC, USA.

Krieger, H.W. (1929) Archaeological and historical investigations in Samaná Dominican Republic. Bulletin of the Smithsonian Institution, 147, 1-91.
La Bastille, A. (1999) Jaguar Totem. West of the Wind Publications, New York, USA.

Lancho, P., Casilla, M. \& Bonnelly, I. (2006) Informe de la Visita de Inspección Preliminar al Santuario de Manatíes de Estero Hondo. Unpublished report. Fundación Dominicana de Estudios Marinos Inc., Santo Domingo, Dominican Republic.

Lefebvre, L.W., Marmontel, M., Reid, J.P., Rathbun, G.B. \& Domning, D.P. (2001) Status and biogeography of the West Indian manatee. In Biogeography of the West Indies: Patterns and Perspectives (eds C.A. Woods \& F.E. Sergile), pp. 425-474. CRC Press, Boca Raton, USA.

Lefebvre, L.W., O’Shea, T.J., Rathbun, G.B. \& Best, R. (1989) Distribution, status, and biogeography of the West Indian manatee. In Biogeography of the West Indies: Past, Present, and Future (ed. C.A. Woods), pp. 567-610. Sandhill Crane Press, Gainesville, USA.

Ley de Pesca No. 1518 (1938) Gaceta Oficial 5187, Ciudad Trujillo, República Dominicana, 29 June 1938.

Ley No. 64-oo (200o) Gaceta Oficial 10056, Santo Domingo de Guzmán, Distrito Nacional, República Dominicana, 18 August 2000.

Lyonnet, C. (180o-1810) Statistique de la Partie Espagnole de Saint-Domingue. De l'Imprimerie de Giguet et Michaud, Paris, France.

MacNutt, F.A. (1912) De Orbe Novo: the Eight Decades of Peter Martyr D'Anghera. G.P. Putnam's Sons, The Knickerbocker Press, New York, USA.

Mañón Arredondo, M.J., Morbán Laucer, F., Cartagena Portalatín, A. \& García Arévalo, M. (1971) Nuevas investigaciones de áreas indígenas al noreste de guayacanes y juan dolio. Revista Dominicana de Arqueología y Antropología, 1, 81-133.

Mateo, J. \& Haughton, M. (2003) A review of the fisheries sector of Haiti with recommendations for its strengthening. Proceedings of the Gulf and Caribbean Fisheries Institute, 54, 60-97.

Mignucci-Giannoni, A.A. (1991) Outlook for manatee survival grim unless rapid action is taken. Sirenews, 15, 7-8.

Mignucci-Giannoni, A.A., Williams, E.H., Toyos-González, G.M., Pérez-Padilla, J., Rodríguez-López, M.A., VegaGuerra, M.B. \& Ventura-González, M. (1999) Helminths from a stranded manatee in the Dominican Republic. Veterinary Parasitology, 81, 69-71.

Miller, G.S. (1916) Bones of mammals from Indian sites in Cuba and Santo Domingo. Smithsonian Miscellaneous Collections, 66, 1-10.

Miller, G.S. (1929) Mammals eaten by Indians, owls, and Spaniards in the coast region of the Dominican Republic. Smithsonian Miscellaneous Collections, 82, 1-18.

Ministerio de Medio Ambiente y Recursos Naturales (2011) Lista de Especies en Peligro de Extinción, Amenazadas y Protegidas de la República Dominicana (Lista Roja). Santo Domingo, Dominican Republic.

Ministerio de Medio Ambiente y Recursos Naturales (2014) Santuario de Mamíferos Marinos Estero Hondo Plan de Manejo 2014-2019. Santo Domingo, Dominican Republic.

Ministerio de Medio Ambiente y Recursos Naturales (2015) Plan de Manejo del Santuario de Mamíferos Marinos Bancos de La Plata y La Navidad. Santo Domingo, Dominican Republic.

Moreau de Saint-Méry, L.E. (1798) Description Topographique, Physique, Civile, Politique e Historique de la Partie Francaise de l'Isle Saint-Domingue. Chez l'AUTEUR, Philadelphia, USA.

Ottenwalder, J.A. (1995) Situación del manatí en la República Dominicana. Dominican Business, 32, 41-44.

Ottenwalder, J.A. (1996) Reportes de Registros y Observaciones de Manatí (yotros Mamíferos Marinos). Unpublished report. Prospectiva Ambiental Dominicana, Santo Domingo, Dominican Republic. 
Ottenwalder, J. \& León, Y. (1999) Resultados del Análisis Inicial de los Surveys (Entrevistas) de Manatí Conducidas en la Costa de República Dominicana entre 1994 y 1996. Unpublished report. Prospectiva Ambiental Dominicana, Santo Domingo, Dominican Republic.

PAULY, D. (1995) Anecdotes and the shifting baseline syndrome of fisheries. Trends in Ecology \& Evolution, 10, 430.

Prospectiva Ambiental Dominicana (1995) Informe de Progreso del Proyecto Promanati. Santo Domingo, Dominican Republic.

Pugibet, E. \& Vega, M. (200o) Informe Sobre el Manatí Antillano (Trichechus manatus) en la República Dominicana. Acuario Nacional, Santo Domingo, Dominican Republic.

Rainey, F.G. (1941) Excavations in the Ft. Liberté region, Haiti. Yale University Publications in Anthropology, 23, 1-48.

Rathbun, G.B., Woods, C.A. \& Ottenwalder, J.A. (1985) The manatee in Haiti. Oryx, 19, 234-236.

Reynolds, J.E. \& MARshall, C.D. (2012) Vulnerability of sirenians. In Sirenian Conservation: Issues and Strategies in Developing Countries (eds E.M. Hines, J.E. Reynolds III, L.V. Aragones, A.A. Mignucci-Giannoni \& M. Marmontel), pp. 12-19. University Press of Florida, Gainesville, USA.

Reynoso, O.S., Sanchez, P., Leon, Y.M., Garcia, N., Casilla, M., Kuker, K. \& Reynolds, J. (2011) Aerial sightings of Antillean manatees (Trichechus manatus manatus) in coastal waters of the southwestern Dominican Republic. In Abstracts of the 19th Biennial Conference on the Biology of Marine Mammals. Society for Marine Mammalogy, Tampa, USA.

Rouse, I. (1941) Culture of the Fort Liberté region, Haiti. Yale University Publications in Anthropology, 24, 1-196.

Self-Sullivan, C. \& Mignucci-Giannoni, A. (2008) Trichechus manatus ssp. manatus. In The IUCN Red List of Threatened Species 2008. Http://dx.doi.org/10.2305/IUCN.UK.2008.RLTS. T22105A9359161.en [accessed 5 May 2016].

Self-Sullivan, C. \& Mignucci-Giannoni, A.A. (2012) West Indian manatees (Trichechus manatus) in the Wider Caribbean Region. In Sirenian Conservation: Issues and Strategies in Developing Countries (eds E.M. Hines, J.E. Reynolds III, L.V. Aragones, A.A. Mignucci-Giannoni \& M. Marmontel), pp. 36-46. University Press of Florida, Gainesville, USA.

Soto-Ricart, H. \& Rodríguez, F.A. (1989) Museo del Hombre Dominicano Catálogo General. Ediciones Culturales PA-PRESEN S.A., Santo Domingo, Dominican Republic.
Swetnam, T.W., Allen, C.D. \& Betancourt, J.L. (1999) Applied historical ecology: using the past to manage for the future. Ecological Applications, 9, 1189-1206.

Thornback, J. \& Jenkins, M. (1982) The IUCN Mammal Red Data Book, Part 1. IUCN, Gland, Switzerland.

UNEP (1995) Regional Management Plan for the West Indian Manatee, Trichechus manatus (CEP Technical Report No. 35). UNEP Caribbean Environment Programme, Kingston, Jamaica. UNEP (2010) Regional Management Plan for the West Indian Manatee, Trichechus manatus (CEP Technical Report No. 48). UNEP Caribbean Environment Programme, Kingston, Jamaica.

Vail, C.S., Vasquez, O.E., Aquino, J., Bordey, M., Bordey, E.T., Simon, M. \& Michaud, E.F. (2011) Haiti Ocean Project (HOP): development of a multidimensional research and education project in Grand Goave, Republic of Haiti. In Abstracts of the 19th Biennial Conference on the Biology of Marine Mammals. Society for Marine Mammalogy, Tampa, USA.

VegA, B. (1983) De los descubrimientos. LXV. Miguel de Cúneo. Savona, 15-28 octubre de 1495. Boletín del Museo del Hombre Dominicano, 18, 237-254.

Veloz Maggiolo, M. (1972) Arqueología Prehistórica de Santo Domingo. McGraw-Hill Far Eastern Publishers, Singapore.

Veloz Maggiolo, M. (1976) Medioambiente y Adaptación Humana en la Prehistoria de Santo Domingo. Ediciones de Taller, Santo Domingo, Dominican Republic.

Veras Mena, D.A. (2014) Análisis de varamientos de mamíferos marinos en la costa de República Dominicana. Thesis, Universidad Autónoma de Santo Domingo, Santo Domingo, Dominican Republic.

Vianna, J.A., Bonde, R.K., Caballero, S., Giraldo, J.P., Lima, R.P., Clark, A. et al. (2006) Phylogeography, phylogeny and hybridization in trichechid sirenians: implications for manatee conservation. Molecular Ecology, 15, 433-447.

Walton, W. (1810) Present State of the Spanish Colonies. Printed for Longman, Hurst, Rees, Orme, and Brown, London, UK.

WiEnER, J. (2013) Toward the Development of Haiti's System of Marine Protected Areas (MPAs). Fondation pour la Protection de la Biodiversité Marine, Haiti.

Woods, C.A. \& Ottenwalder, J.A. (1992) The Natural History of Southern Haiti. Department of Natural Sciences, Florida Museum of Natural History, University of Florida, Gainsville, USA. 